\title{
28. TWO SEISMIC REFRACTION PROFILES IN THE WEST PHILIPPINE SEA ${ }^{1}$
}

\author{
M. Henry, ${ }^{2}$ D. E. Karig, ${ }^{3}$ and G. G. Shor, Jr. ${ }^{2}$
}

\section{INTRODUCTION}

The results of two reversed refraction profiles made in the west Philippine Sea by Thomas Washington on Cruise Tasaday V in September 1973 are presented. SSQ-41 expendable military sonobuoys were used as receivers and explosives as a sound source on both stations. Station 5-2 was purposely located over Leg 31 DSDP Sites 294/295 where drilling had only been successful to the bottum of the thin sediment cover, about 150 meters maximum (Site Report Chapter 6, this volume). It is an area of relatively smooth bottom topography (100 m maximum relief along Station 5-2) with an average water depth of $5.75 \mathrm{~km}$. Station 5-3 was located approximately $290 \mathrm{~km}$ to the southwest of Sites $294 / 295$, just south of the Central Basin fault. The topography is hilly ( $800 \mathrm{~m}$ relief along Station 5-3) with an average water depth of $5.50 \mathrm{~km}$ (Figure 1).

\section{DATA ANALYSIS}

Data analysis used was that described by Ewing (1963) for reversed profiles, assuming plane dipping layers. The arrival times of the refracted waves were corrected for shot and hydrophone depths and for variations in the topography, assuming that basement topography parallels the bottom topography, and using a sloping datum which best fits the bathymetry. Corrections for actual sediment thickness variations could not be used for these stations because of incomplete reflection records. Lines were fitted to the corrected traveltime data by the method of least squares. The velocities and layer thicknesses for these stations have been tabulated in Table 1. The travel-time plots of each line and their respective individual solutions are shown in Figures 2 and 3. These data have been "reduced" by a velocity of $7.00 \mathrm{~km} / \mathrm{sec}$ in order to expand the vertical scale for ease of data analysis. The cross-sections below each set of plots depict the reversed solutions. Since extensive drift on Station 5-2 did not permit this profile to be truly reversed, the reverse times were not required to be identical. On Station 5-3, however, a common reverse-point solution was used. For both stations, a velocity of $1.60 \mathrm{~km} / \mathrm{sec}$ was assumed for the sediment

\footnotetext{
Contribution of the Scripps Institution of Oceanography, new series.

${ }^{2}$ Marine Physical Laboratory of the Scripps Institution of Oceanography, University of California, San Diego, La Jolla, California 92037.

'Department of Geological Sciences, Cornell University, Ithaca, N. Y. 14850
}

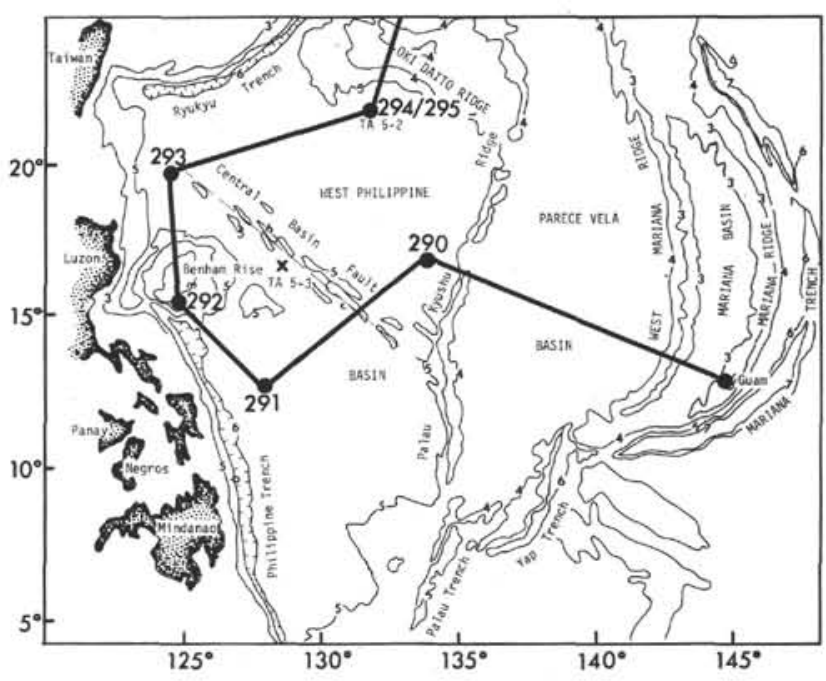

Figure 1. Location of Tasaday Stations 5-2, 5-3 and Leg 31 Sites 294-295. From map: "Topography of North Pacific" T. E. Chase, H. W. Menard, and J. Mammerickx, Institute Marine Resources, Geol. Data Center, Scripps Institution of Oceanography, 1971. Contour depths in kilometers. Scale 1:6,500,000.

layer based on drilling and on site reflection profiles obtained during Leg 31.

\section{DISCUSSION}

The sediment cover at both stations is very thin (average of $215 \mathrm{~m}$ for both stations). Sites 294/295 drilled through 104 and 155 meters, respectively, before reaching basalt basement (Site Report Chapter 6, this volume). This corresponds well to the refraction results of 160 meters sediment thickness for line 2 of Station 52 , located over this site. This also closely matches the 156 meters estimated from a Tasaday reflection record segment obtained near the middle of that line. Station 53 has only a small segment of reflection record of poor quality at the beginning of line 1 , giving an estimated maximum thickness of 96 meters, compared to the 94 meters calculated from refraction data for that line. Murauchi et al. (1968), assuming a $2 \mathrm{~km} / \mathrm{sec}$ velocity, estimated an overall average of 100 meters for sediment thickness in the Philippine Sea.

Table 2 gives a comparison of the crustal velocities and thicknesses presented here with those found by Murauchi et al. (1968) in the Philippine Sea, and averages compiled by Raitt (1963) for the western north Pacific. At Station 5-2, the $5.76 \mathrm{~km} / \mathrm{sec}$ velocity for layer 2 , corresponding to basalt basement at Sites $294 / 295$, is higher than the averages in both the Philippine Sea and 
TABLE 1

Reversed Seismic Stations in the Philippine Sea

\begin{tabular}{|c|c|c|c|c|c|c|c|c|c|c|c|c|c|}
\hline \multirow[b]{2}{*}{ Station } & \multirow[b]{2}{*}{ Position } & \multirow[b]{2}{*}{ Azimuth } & \multicolumn{5}{|c|}{ Velocity $(\mathrm{km} / \mathrm{sec})$} & \multirow{2}{*}{$\begin{array}{l}\text { Water } \\
\text { Depth } \\
(\mathrm{km})\end{array}$} & \multicolumn{4}{|c|}{ Thickness (km) } & \multirow{2}{*}{$\begin{array}{c}\text { Total } \\
\text { Depth } \\
\text { to } \\
\text { Mantle } \\
(\mathrm{km})\end{array}$} \\
\hline & & & 1 & 2 & 3 & 4 & 5 & & 1 & 2 & 3 & 4 & \\
\hline TA $5-2-1$ & $\begin{array}{r}22^{\circ} 43.1^{\prime} \mathrm{N} \\
131^{\circ} 23.9^{\prime} \mathrm{E}\end{array}$ & 178 & & & & & & 5.73 & 0.31 & 0.70 & 0.11 & 3.32 & 10.17 \\
\hline TA 5-2-2 & $\begin{array}{r}22^{\circ} 16.4^{\prime} \mathrm{N} \\
131^{\circ} 24.4^{\prime} \mathrm{E}\end{array}$ & 347 & $1.60^{\mathrm{a}}$ & 5.76 & 6.23 & 6.69 & 7.99 & 5.81 & 0.16 & 0.56 & 0.33 & 3.72 & 10.58 \\
\hline TA $5-3-1$ & $\begin{array}{r}16^{\circ} 57.5^{\prime} \mathrm{N} \\
128^{\circ} 11.8^{\prime} \mathrm{E}\end{array}$ & 355 & & & & & & 5.05 & 0.09 & 1.62 & 1.55 & - & - \\
\hline TA $5-3-2$ & $\begin{array}{r}17^{\circ} 23.9^{\prime} \mathrm{E} \\
128^{\circ} 09.9^{\prime} \mathrm{E}\end{array}$ & 185 & $1.60^{\mathrm{a}}$ & 5.04 & 6.30 & 7.12 & - & 5.75 & 0.30 & 0.82 & 2.24 & - & - \\
\hline
\end{tabular}

${ }^{\mathrm{a}}$ Assumed velocity.

TABLE 2

Comparison of Philippine Sea and Pacific Ocean

\begin{tabular}{|c|c|c|c|c|c|c|c|}
\hline Station & $\begin{array}{l}\text { Layer } 2 \\
\text { Velocity } \\
(\mathrm{km} / \mathrm{sec})\end{array}$ & $\begin{array}{l}\text { Average } \\
\text { Thickness } \\
(\mathrm{km})\end{array}$ & $\begin{array}{l}\text { Layer } 3 \\
\text { Velocity } \\
(\mathrm{km} / \mathrm{sec})\end{array}$ & $\begin{array}{c}\text { Average } \\
\text { Thickness } \\
(\mathrm{km})\end{array}$ & $\begin{array}{l}\text { Layer } 4 \\
\text { Velocity } \\
(\mathrm{km} / \mathrm{sec})\end{array}$ & $\begin{array}{l}\text { Thickness } \\
(\mathrm{km})\end{array}$ & $\begin{array}{c}\text { Mantle } \\
\text { Velocity } \\
(\mathrm{km} / \mathrm{sec})\end{array}$ \\
\hline \multicolumn{8}{|c|}{ Tasaday, Philippine Sea } \\
\hline TA $5-2$ & 5.76 & 0.63 & 6.23 & 0.22 & 6.69 & 3.52 & 7.99 \\
\hline TA $5-3$ & 5.04 & 1.22 & 6.30 & 1.90 & 7.12 & - & - \\
\hline \multicolumn{8}{|c|}{ Philippine Sea (Murauchi et al., 1968) } \\
\hline & $\begin{array}{r}4.85 \\
\pm 0.18\end{array}$ & $\begin{array}{r}1.27 \\
\pm 0.30\end{array}$ & $\begin{array}{r}6.70 \\
\pm 0.10\end{array}$ & $\begin{array}{r}4.29 \\
\pm 0.80\end{array}$ & & & $\begin{array}{r}8.23 \\
\pm 0.15\end{array}$ \\
\hline \multicolumn{8}{|c|}{ Western North Pacific (Raitt, 1963) } \\
\hline & $\begin{array}{r}5.02 \\
\pm 0.63\end{array}$ & $\begin{array}{r}2.05 \\
\pm 0.50\end{array}$ & $\begin{array}{r}6.73 \\
\pm 0.25\end{array}$ & $\begin{array}{r}5.08 \\
\pm 1.72\end{array}$ & & & $\begin{array}{r}8.21 \\
\pm 0.18\end{array}$ \\
\hline
\end{tabular}

the Pacific, and also notably thinner. Even if the thin layer 3 of this station were added to layer 2, the result would still be less than half the average thickness of layer 2 found in the western north Pacific. The 6.23 $\mathrm{km} / \mathrm{sec}$ layer 3, found also at Station 5-3, but of greater thickness, is of intermediate velocity between basement and oceanic layer values in normal oceanic sections. This sequence of layers has only occasionally been found in the Pacific, but has been reported at several stations in the New Caledonia Basin area by Shor et al. (1971). The Melanesian area, like the Philippine Sea area, is made up of marginal basins and ridges believed to have been formed by extensional processes relating to island-arc-trench tectonics (Karig, 1971). A layer of 6.2$6.3 \mathrm{~km} / \mathrm{sec}$ velocity and varying thickness as shown here could represent basaltic rock in a physical state intermediate between flows and gabbroic intrusions.

Layer $4(6.69 \mathrm{~km} / \mathrm{sec})$ of Station 5-2, corresponding to layer 3 of Raitt's and Murauchi's data, is consistent in velocity to both areas, but still notably thinner than the Pacific value, but within the range of the Philippine Sea values.
On Station 5-3, layer $2(5.04 \mathrm{~km} / \mathrm{sec})$ is similar in velocity to layer 2 of both Philippine Sea and Pacific areas and closely matches Murauchi's average thickness for that layer, which is thinner than in the Pacific. Layer $4(7.12 \mathrm{~km} / \mathrm{sec})$ of this station, again corresponding to Murauchi's and Raitt's layer 3, is of notably higher velocity. It is possible that the velocities obtained for layers 3 and 4 on this station were affected by the hilly topography, which was assumed to be controlled by layer 2. If layer 3 does represent a form of basaltic rock, this area could be expected to have local variations in basement and/or oceanic layer thicknesses which would not be compensated for in the topographic correction technique used for these data. Since mantle was not reached on Station 5-3, the thickness of layer 4 and comparison of total crustal thickness here with the Pacific values cannot be made.

\section{CONCLUSIONS}

The thin sediment cover found at Sites 294/295 is consistent with seismic refraction and reflection data presented here. Refraction data indicate a slight thicken- 


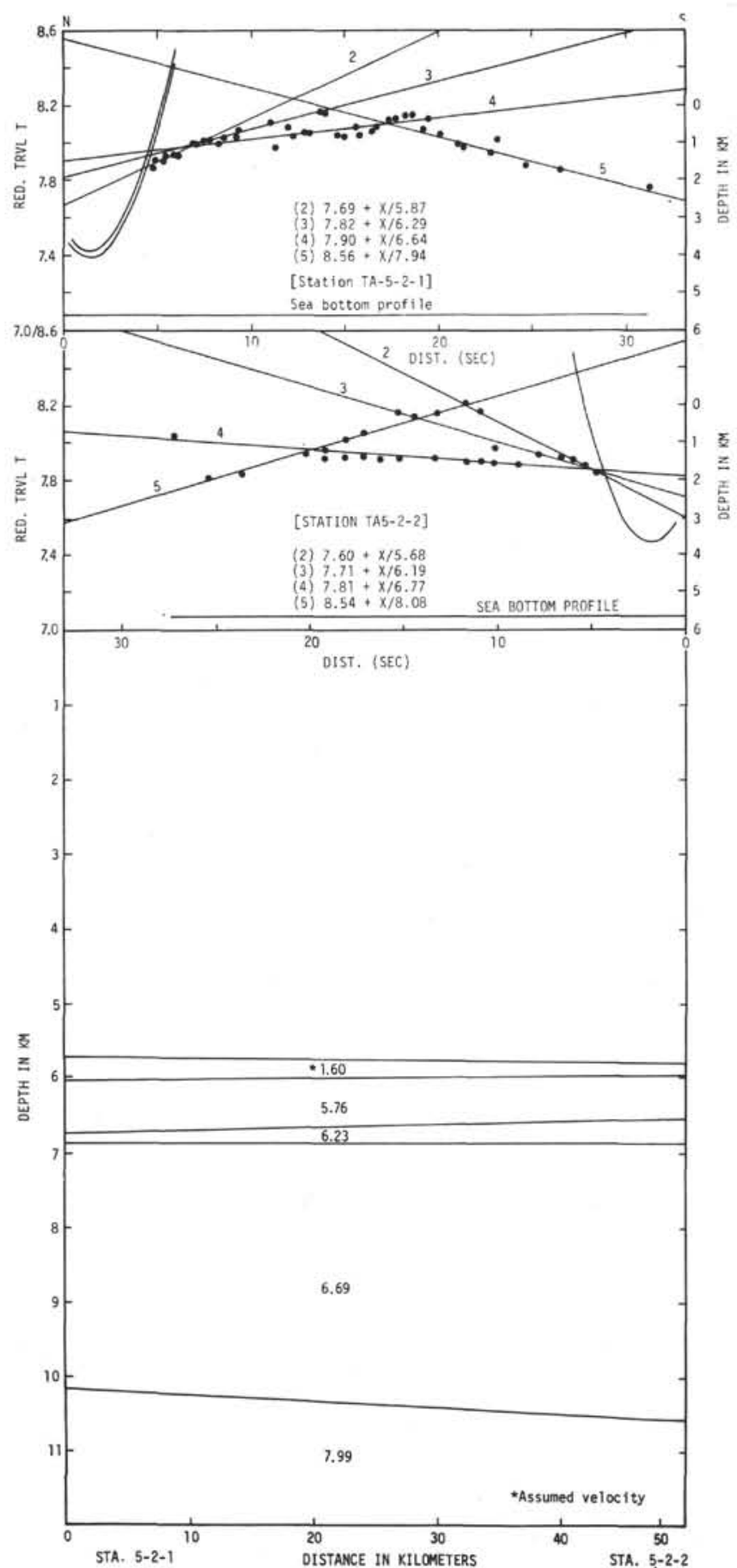

Figure 2. Reduced travel time plots (top, middle), and reversed layer solution (bottom) for Station TA-5-2.

ing of sediments to the north toward the Oki Daito Ridge, suggesting that as a possible source for some of the sediment (Site Report Chapter 6, this volume). Velocities of crustal layers 2 and 4 in these two Philippine Sea profiles resemble those of normal oceanic crust. However, the crust is thinner than normal oceanic averages and contains a $6.2-6.3 \mathrm{~km} / \mathrm{sec}$ layer of varying thickness which may represent basaltic rock of a character intermediate to that of the second and fourth

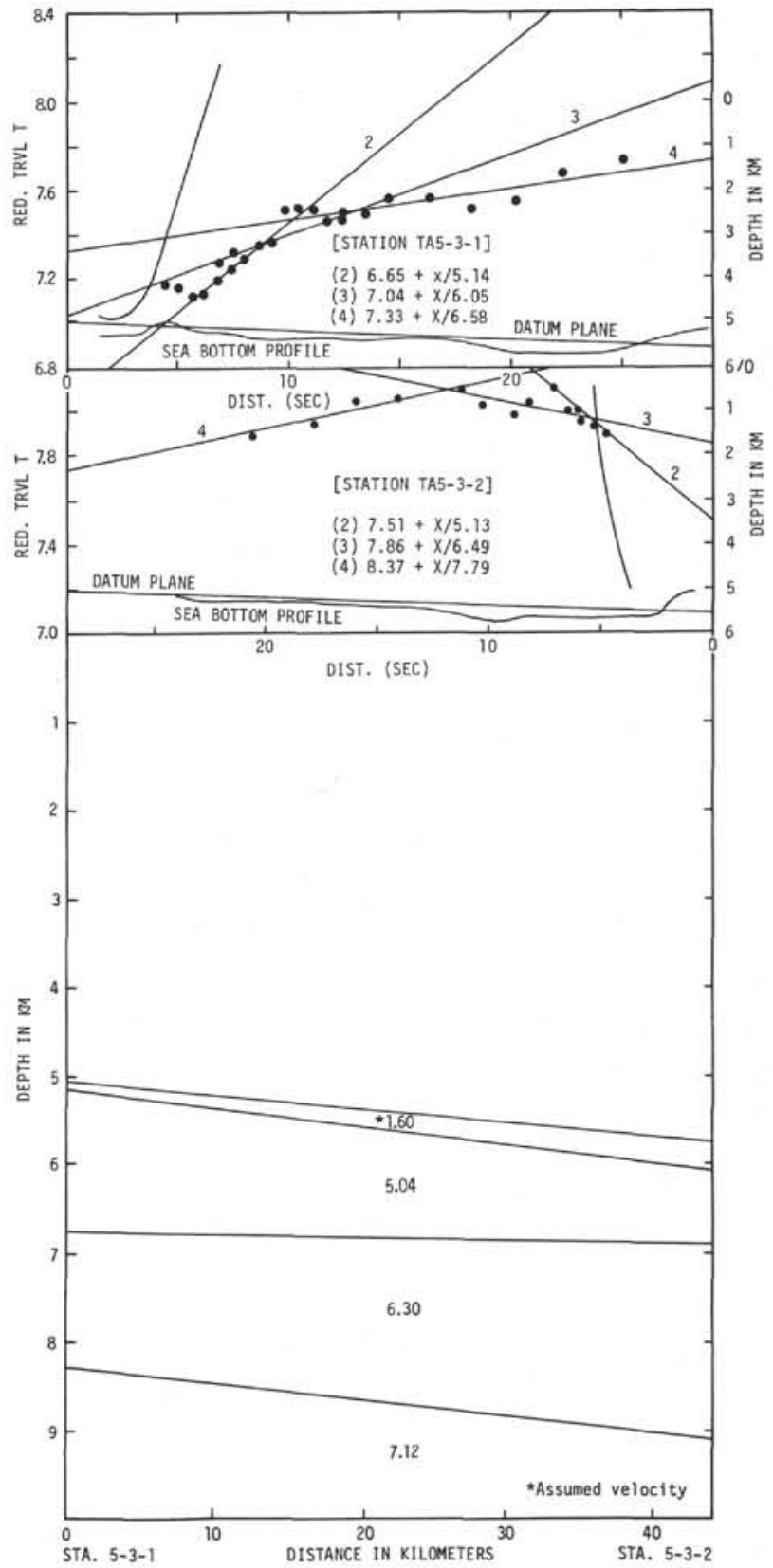

Figure 3. Reduced travel time plots (top, middle), and reversed layer solution (bottom) for Station TA-5-3.

layers. These data point favorably to an extensional origin for the Philippine Basin.

\section{ACKNOWLEDGMENTS}

This work was supported by National Science Foundation Grant GA-37998 and by the Office of Naval Research.

\section{REFERENCES}

Ewing, J. I., 1963. Elementary theory of seismic refraction and reflection measurements. In Hill, M. N. (Ed.), The sea: New York (Interscience), v. 3, p. 3-17.

Karig, D., 1971. Origin and development of marginal basins in the western Pacific: J. Geophys. Res., v. 76, no. 11, p. 25422561 . 
Murauchi, S., Den, N., Asano, S., Hotta, H., Yoshi, T., Asanuma, T., Hagiwara, K., Ichikawa, K., Sato, T., Ludwig, W. J., Ewing, J. I., Edgar, N. T., and Houtz, R. E., 1968. Crustal structure of the Philippine Sea: J. Geophys. Res., v. 73 , no 10 , p. 3143-3172.
Raitt, R. W., 1963. The crustal rocks. In Hill, M. N. (Ed.)., The sea: New York (Interscience), v. 3, p. 85-109.

Shor, G. G. Jr., Kirk, H. K., and Menard, 1971. Crustal structure of the Melanesian area: J. Geophys. Res., v. 76, no. 11, p. $2562-2586$. 